\title{
ANALYSIS OF MILK CONSUMPTION BEHAVIOR AND PROCESSED PRODUCTS ON IPB STUDENTS WITH AIDA AND CRI METHODS
}

\author{
Widya Bella Widaryanti*)1, Retnaningsih* \\ *Department of Family and Consumer Sciences, Faculty of Human Ecology, \\ Bogor Agricultural University \\ ${ }^{1}$ Corresponding author:widyabella@gmail.com
}

\begin{abstract}
This study aimed to analyze consumption behaviour of Fapet's milk and processed products using the AIDA and CRI models. Samples in this study were 209 active students of IPB in 2nd, 4th, and 6th semester that chosen using simple random sampling method. The results showed that there was a correlation between awareness and interest, interest and desire, while desire has no correlation with action. The results also showed that gender, pocket money, father's occupation, family size, awareness, interest, and action significantly correlate with consumption frequency of Fapet's milk and processed products. Awareness, interest, and action variables also correlate with consumption quantity of Fapet's milk and processed products. The enhancement of awareness and action will increase consumption frequency and consumption quantity of Fapet's milk and processed products. Results of Customer Response Index (CRI) analysis showed that students response to dairy Fapet milk and processed products were 78.9 percent indicating that marketing strategy has been effective.
\end{abstract}

Keywords: AIDA, consumption behaviour, CRI

\begin{abstract}
Abstrak. Penelitian ini bertujuan menganalisis perilaku konsumsi susu Fapet dan hasil olahannya dengan modelAwareness, Interest, Desire, and Action(AIDA)dan Customer Response Index (CRI). Contoh pada penelitian ini 209 mahasiswa aktif IPB semester 2, 4, dan 6 yang dipilih secara acak sederhana. Hasil penelitian menunjukkan terdapat hubungan antara kesadarandan ketertarikan, ketertarikandan keinginansedangkan keinginan tidak memiliki hubungan dengan tindakan. Hasil penelitian juga menunjukkan bahwa jenis kelamin, uang saku, pekerjaan ayah, besar keluarga, kesadaran, ketertarikan, dan tindakan memiliki hubungan dengan frekuensi konsumsi susu Fapet dan hasil olahannya. Variabel kesadaran, ketertarikan, dan tindakan juga memiliki hubungan dengan jumlah jenis susu Fapet dan hasil olahannya yang dikonsumsi. Semakin tinggi kesadaran dan tindakan maka semakin tinggi frekuensi dan jumlah jenis susu Fapet dan hasil olahannya yang dikonsumsi. Berdasarkan hasil analisis Customer Response Index (CRI), respon mahasiswa terhadap produk susu Fapet dan hasil olahannya sebesar 78.9 persen menunjukkan bahwa strategi pemasaran yang dilakukan produsen telah efektif.
\end{abstract}

Kata kunci: $A I D A, C R I$, perilaku konsumsi 


\section{Introduction}

Milk is a fatty emulsion in the aqueous solution of sugar and mineral salts with proteins in a colloidal state. Normally milk contains average fat as much as 3.8 percent, 3.2 percent protein, 4.7 percent lactose, 0.855 ash, 87.25 percent water and 12.75 percent dry matter. In addition, milk also has high nutritional value and has good properties to support human health (Anjasari, 2010). Bogor Agricultural University (IPB) is a college that has produced many innovation products both in food and non-food products. One of them is Fapet milk produced by Faculty of Animal Science IPB in collaboration with PT Agriprima. On Milk Day Nusantara (HSN) which coincides on 1 June, Faculty of Animal Science IPB held a seminar on the importance of consuming milk. A warning HSN is expected to improve the culture of drinking milk by the community to increase the production and consumption of the community which causes the development of rural agroindustry to increase and farmers to benefit ${ }^{1}$. Milk consumption in Indonesia is still low at $13.5 \mathrm{l} / \mathrm{cap} /$ year compared to other ASEAN countries, such as Singapore of 46.1 1/cap/year and Malaysia of 53.6 1/cap/year ${ }^{2}$.

Behavior of milk consumption can increase the calcium intake in the body. Adolescent encouraged to consume milk as a main beverages because milk is a primary source of calcium needed for bone health (Suryono, et al. 2007). Calsium and vitamin D is also an essential nutrient for young adults to assist the growth of bone, dental health, control cholesterol, and high blood pressure for adults $^{3}$. Students fall into the category of adolescence at the end of early adult age.

Manufacturers make marketing efforts for consumers to buy a product. One of the marketing efforts that can be done is by using the AIDA model. The AIDA model was introduced to explain how consumers change their behaviour and take action to buy products (Familmaleki et al., 2015). According to Rogers (2003) to change consumer behaviour is to communicate information about new ideas more quickly. Therefore, when consumers are already exposed, consumers tend to expose themselves to products that match their interests, needs, and brand actions. According to $\mathrm{Li}$ and $\mathrm{Yu}$ (2013), the AIDA model includes the first four stages with a meaningful awareness step to attract awareness from consumers. Both interests, arouse consumer interest in a product by demonstrating the benefits and benefits of the product. Third desire, convince consumers that they want and want the product and that it will satisfy their needs. The fourth stage of action, consumers take the final decision to buy or consume products. According Rawal (2013) invites consumers to provide discounts or promotions with time constraints is one way for consumers to act quickly on a product. The AIDA model is also commonly

\footnotetext{
${ }^{1}$ http://intp.fapet.ipb.ac.id/ intp/index.php/arsip-berita/9-berita/Berita/202-seminar [16 Oktober 2017]

${ }^{2}$ http://jabarprov.go.id/index.php/news/16592/2016/03/24/Konsumsi-Susu-di-IndonesiaTerendah [1 April 2017]

${ }^{3}$ https://www.cnnindonesia.com/gaya-hidup/20170418202443-255-208504/konsumsi-susutetap-penting-bagi-orang-dewasa/ [22 juli 2017]
} 
used to measure the effectiveness of new products among all consumers (Kotler \& Armstrong, 2008). The AIDA model is also a tool to encourage action by stimulating purchases or consuming certain products or services (Ghirvu, 2013).

Previous studies conducted by Ugonna et al., (2014) states that only two variables of awareness and interest have a significant positive effect on the action. But in a study by Johar et al. (2015) states that awareness, interest, desire, action has a significant influence on testing together. These stages will lead to consumer response to a product measured by Customer Response Index (CRI). Based on the description above, the researchers are interested to examine the consumption behaviour of milk Fapet with AIDA and CRI methods.

The aims of this study, namely: (1) to identify student characteristics, family characteristics, the level of awareness, interest, desire, action, and behavior of milk consumption Husbandryand processed products at IPB students; (2) to analyze relationship student characteristics, family characteristics, awareness, interest, desire, action with consumption behavior of Fapet milk and its processed products ; (3) to analyze the affect of student characteristics, family characteristics, awareness, interest, desire, and action on Fapet milk consumption behavior and its processed products; and (4) to analyze how much the student's IPB response to a Fapet dairy product and its processed products.

\section{Method}

This research uses cross-sectional study design. The selection of research sites was conducted based on the consideration that the Campus IPB Dramaga is one of the early locations of dairy products Fapet IPB developed from ordinary milk into various forms of dairy products of interest and the consideration of ease of accessibility. Primary data collection conducted in May to June 2017. This research is umbrella research with the theme "Behavior Consumption of Milk and Processed Results on IPB Students". The population of this study is the active students of the regular Bachelor Program (S1) IPB in two to six semesters in the academic year 2016/2017 as many as 10.659 people. The sampling technique used simple random sampling. Determination of minimum sample amount using Slovin formula with leeway 0.07 . The results of calculations with the Slovin formula, showing the minimum number of 200 students. The number of samples taken in this study amounted to 209 students.

The data collected in this study is the primary data. Primary data were obtained through interviews using questionnaires modified from Murdiani (2012) and Sis \& Albari (2015) which have been tested previously to 30 respondents. Primary data include student characteristics (age, gender, and pocket money), family characteristics (parental occupation, family size and family income), consciousness (awareness) with Cronbach alpha 0.330, interest with a Cronbach alpha 0.419, desire with Cronbach alpha 0.437, action, and the consumption behavior (frequency and number of types of animal milk and processed products). The cut-off of awareness, low (<46.67), moderate (46.6773.34), and high (> 73.34). Interest, low $(<48.33)$, moderate $(48.33-71.66)$, and high $(>71.66)$. For desire the category are low $(<63.33)$, moderate $(63.33-81.66)$, 
and high (> 81.66). Meanwhile, for the action is assumed that who do not consume included in the low category and who consume included in the high category. In addition, for the behaviour of milk consumption is categorized by a cut off that has been determined. The frequency of consumption of milk Fapet and its processed products is divided into three categories, i.e. rarely $(<16$ time/month), often (16-28 time/month), and very often (> 28 time/month). The amount of milk Fapet and its processed products consumed is divided into five categories, i.e., not consuming, 1-2 types, 3-4 types, 5-6 types, 7-9 types. Furthermore, milk products Fapet and its processed products will be called with milk Fapet.

Data analysis is descriptive and inferential analysis. Inferential analysis conducted in this research are correlation test, regression test, and Customer Response Index (CRI) test. The correlation test is used to know the relationship between some variables. The regression test is used to find out the influence of one free variable to one bound variable. AIDA analysis is used to measure the effectiveness of a product through the four stages of awareness, interest, desire, and action. Customer Response Index (CRI) was used to view student responses to a product.

\section{Result}

\section{Characteristics of Students and Family Characteristics}

In this study, the number of female students more by 54.1 percent compared to the value of the percentage of male gender with a percentage of 45.9 percent.The amount 88.5 percent of the students are in the early adult category, the remaining 11.5 per cent are in the category of late adolescence. More than half (72.7\%) of students' pocket money ranged from Rp 600.001 to $\mathrm{Rp} 1.200 .000$ with an average student allowance per month of Rp 1.105.263. More than half (65.1\%) of students are in small families $(\leq 4)$. A total of 52.6 percent of student fathers have jobs as civil servants /army/police, and more than half $(68.9 \%)$ of student mothers are unemployed or housewives. Almost all (95.2\%) student per capita income is categorized as non-poor. The average per capita income in this study amounted to Rp 1.308.019. Consumers with higher income levels pay more attention to the quality and hygienic properties of dairy products consumed (Bousbia et al., 2017).

\section{AIDA Analysis}

Differences in the characteristics of each student can affect the level of awareness, interest, desire, and action on a product. The results showed that the awareness and interest in dairy products husbandry at high category with the percentage of each 83.3 percent and 60.3 percent. This shows that awareness and interest have a relationship. Students desire in dairy products Husbandry moderate category $(74.2 \%)$. This is the marketing theory that states that consumer interest does not necessarily affect consumer desire in consuming a product. Students action is in the high category (94.3\%) with the assumption that does not consume and consume relatively low category classified as the high category. This can be seen in Table 1. 
Tabel 1 Distribution of students based on AIDA dimension on Fapet milk products

\begin{tabular}{|c|c|c|c|c|c|c|c|c|c|c|}
\hline \multirow{3}{*}{ Dimension } & \multicolumn{6}{|c|}{ Category } & \multirow{2}{*}{\multicolumn{2}{|c|}{ Total }} & \multirow{3}{*}{ Min-max } & \multirow{3}{*}{ Average $\pm \mathrm{Sd}$} \\
\hline & \multicolumn{2}{|c|}{ Low } & \multicolumn{2}{|c|}{ Moderate } & \multicolumn{2}{|c|}{ High } & & & & \\
\hline & $\mathrm{n}$ & $\%$ & $\mathrm{n}$ & $\%$ & $\mathrm{n}$ & $\%$ & $\mathrm{n}$ & $\%$ & & \\
\hline Awareness & 8 & 3.8 & 27 & 12.9 & 174 & 83.3 & 209 & 100.0 & $20-100$ & $85.4 \pm 17.60$ \\
\hline Interest & 1 & 1.0 & 81 & 38.8 & 126 & 60.3 & 209 & 100.0 & $25-95$ & $73.0 \pm 10.0$ \\
\hline Desire & 28 & 13.4 & 155 & 74.2 & 26 & 12.4 & 209 & 100.0 & $45-100$ & $72.0 \pm 10.0$ \\
\hline Action & 12 & 5.7 & 0 & 0 & 197 & 94.3 & 209 & 100.0 & $0-1$ & $0.94 \pm 0.23$ \\
\hline
\end{tabular}

\section{Consumption Behavior of Milk and Processed Products}

\section{Frequency, Number of Types, Types of Milk and Processed Products}

The behaviour of milk consumption and its processed products in each student is different. It can be seen in Table 2 that students have a frequency of consumption of milk Fapet which varies from 0 time/month to 52 time/month with an average of 18.4 time/month. Almost half (49.8\%) of students still rarely consume Fapet milk. Only 30.1 percent of students who consumed Fapet milk at 28 time/month. A total of 56.5 percent of students are very often consume milk and processed products with other brands with an average frequency of consumption of 31.15 time/month.

In addition, the number of types of milk consumed Fapet students are in the category 1-2 types of milk Fapet with a percentage of 79.4 percent. Only 1.4 percent of those who consume 5-6 types of milk Fapet offered, namely pasteurized plain milk, pasteurized flavour milk, yoghurt, pudding, ice milk mambo, and kefir. This is because of the six types of products offered are still rare students who know and consume mambo milk products and kefir. Meanwhile, the amount of milk and its processed products with other brands consumed by students are in the category of 3-4 types with a percentage of 70.3 percent. Only 4.8 percent of students who consume 1-2 types of milk and processed products with other brands.

Based on the type of milk and its processed products that consumed, almost all (93.3\%) students consume pasteurized flavour milk with the brand of Fapet milk. Not just pasteurized milk flavor, more than half (51.2\%) of students consume UHT milk flavor. Only 2.4 percent of students consume kefir drinks. It can be concluded that milk and other dairy products with other brands more easily found and obtained compared with milk Fapet so that the frequency and amount of types is consumed with other brands more. 
Tabel 2 Distribution of students by frequency, number of types, and type of milk and processed products consume

\begin{tabular}{|c|c|c|c|c|}
\hline \multirow{2}{*}{$\begin{array}{l}\text { Consumption Behavior of Milk and Processed } \\
\text { Products }\end{array}$} & \multicolumn{2}{|c|}{ Fapet Milk } & \multicolumn{2}{|c|}{ Non-Fapet Milk } \\
\hline & $\mathrm{n}$ & $\%$ & $\mathrm{n}$ & $\%$ \\
\hline \multicolumn{5}{|l|}{ Frequency of Consumption } \\
\hline Rarely $(<16 \mathrm{kl} / \mathrm{bl})$ & 104 & 49.8 & 66 & 31.6 \\
\hline Often $(16-28 \mathrm{kl} / \mathrm{bl})$ & 42 & 20.1 & 25 & 12.0 \\
\hline Very Often $(>28$ kl/bl) & 63 & 30.1 & 118 & 56.5 \\
\hline Total & 209 & 100.0 & 209 & 100.0 \\
\hline Average & \multicolumn{2}{|c|}{18.4} & \multicolumn{2}{|c|}{31.15} \\
\hline \multicolumn{5}{|l|}{ Number of types consumed } \\
\hline Not consume & 12 & 5.7 & 0 & 0 \\
\hline 1-2 types & 166 & 79.4 & 10 & 4.8 \\
\hline $3-4$ types & 28 & 13.4 & 147 & 70.3 \\
\hline 5-6 types & 3 & 1.4 & 52 & 24.9 \\
\hline $7-9$ types & 0 & 0 & 0 & 0 \\
\hline Total & 209 & 100.0 & 209 & 100.0 \\
\hline \multicolumn{5}{|l|}{ Type consumed } \\
\hline Pasteurized plain milk & 50 & 23.9 & 15 & 7.2 \\
\hline Pasteurized flavor milk & 195 & 93.3 & 47 & 22.5 \\
\hline Yoghurt & 68 & 32.5 & 92 & 44.0 \\
\hline Pudding & 15 & 7.2 & 49 & 23.4 \\
\hline Mambo ice milk & 16 & 7.7 & 0 & 0 \\
\hline Kefir & 5 & 2.4 & 0 & 0 \\
\hline UHT plain milk & 0 & 0 & 45 & 21.5 \\
\hline UHT milk flavor & 0 & 0 & 107 & 51.2 \\
\hline Sterile milk & 0 & 0 & 72 & 34.4 \\
\hline
\end{tabular}

\section{Brand of Milk and processed products consumed}

The brand of milk and its dairy products consumed by each individual must be different. Almost all students consumed Fapet milk with percentage 94.3 percent. In addition, some students also consume Ultra Milk with a percentage of 53.6 percent. As many as 42.6 percents of students also consume milk and processed products under the brand Cimory. This shows that every student consumes milk and processed products with more than one brand. Meanwhile, students still rarely consume milk and processed products with brands of diamond, king filth, huis milk, sour sally, guma-guma, elle vire, swallow, and colony. It is shown in Table 3 that only 0.5 percent of students consume these brands

Tabel 3 Distribution of students based on brand milk and the processed products consumed

\begin{tabular}{lrr}
\hline Brand of Milk and processed products consumed & $\mathrm{n}$ & $\%$ \\
\hline Fapet's Milk & 197 & 94.3 \\
Bear Brand & 72 & 34.4 \\
Ultra Milk & 112 & 53.6 \\
Frisian Flag & 19 & 9.1 \\
Diamond & 1 & 0.5 \\
Cimory & 89 & 42.6 \\
Indomilk & 38 & 18.2
\end{tabular}




\begin{tabular}{lrr}
\hline Brand of Milk and processed products consumed & $\mathrm{n}$ & $\%$ \\
\hline Green Field & 6 & 2.9 \\
King Filth & 1 & 0.5 \\
Nasional's Pure Milk & 6 & 2.9 \\
Hilo & 3 & 1.4 \\
Milo & 13 & 6.2 \\
Huis Milk & 1 & 0.5 \\
Home Industry & 23 & 11.0 \\
Yogurt & 2 & 1.0 \\
Heaven Blush & 2 & 1.0 \\
Sour Sally & 1 & 0.5 \\
Guma-guma & 1 & 0.5 \\
Elle Vire & 1 & 0.5 \\
Nutrijel & 19 & 9.1 \\
KFC & 2 & 1.0 \\
Puyo & 2 & 1.0 \\
Swallow & 1 & 0.5 \\
My jeli & 2 & 1.0 \\
Coloni & 1 & 0.5 \\
\hline
\end{tabular}

\section{Customer Response Index (CRI)}

Based on CRI analysis, in the first stage shows that all students are exposed to Fapet dairy products. In the second stage, only 96.2 percent of students are aware and understand the product. In the third stage, as many as 99 percents of students are interested to consume Fapet milk. In the fourth stage, the students' desire to consume Fapet milk is 88.4 percent. Furthermore, students who managed to get to the final stage of consuming Fapet dairy products and its processed products as much as 93.8 percent of students. It can be seen in Figure 1.

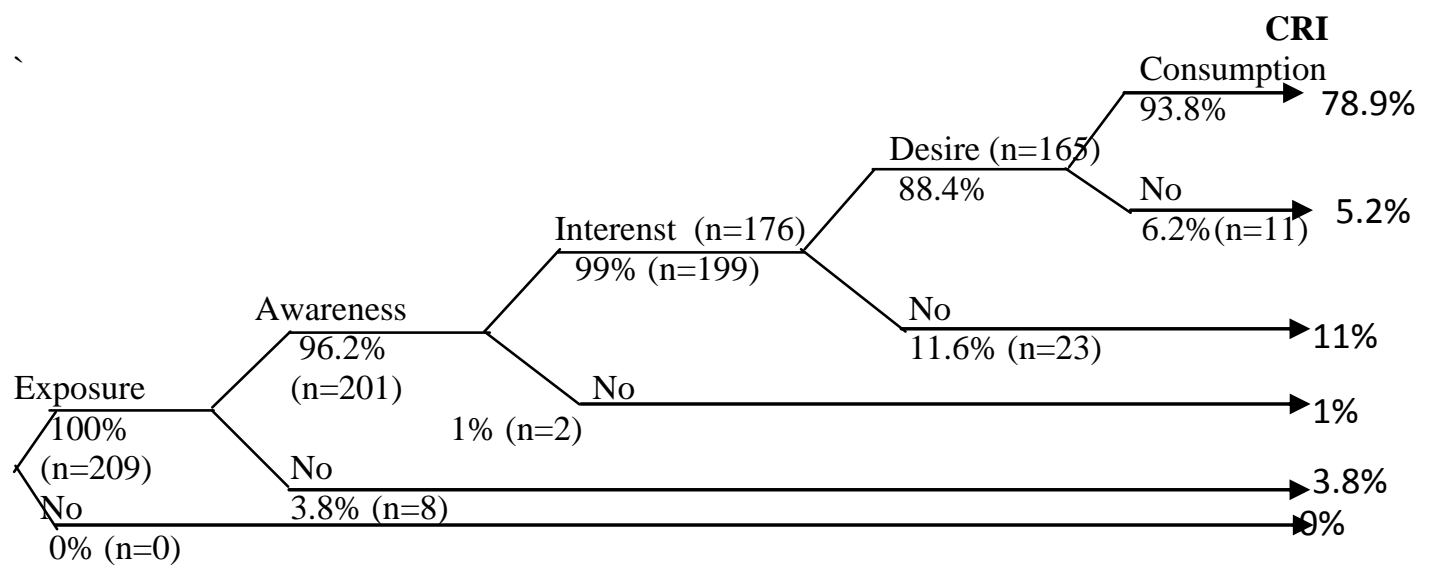

Figure 1. The result tree diagram of Customer Response Index

To find out the results of $C R I$ can be calculated using the formula, as follows:

$$
\begin{aligned}
\text { CRI } & =\% \text { exposure } \times \% \text { awareness } \times \text { \%interest } \times \text { \%desire } \times \text { \%consumption } \\
& =1 \times 0.962 \times 0.99 \times 0.884 \times 0.938 \\
& =\mathbf{0 . 7 8 9}=\mathbf{7 8 . 9} \%
\end{aligned}
$$


CRI results for Fapet dairy products and their processed products amounted to 78.9 percent. That is, the student's response to Fapet milk products has been effective. The product is said to be effective if the value of CRI reaches 40 percent (Best, 2009 in Anugrah, 2013).

\section{Correlations of Student Characteristics, Family Characteristics, Awareness, Interest, Desire, Action, and Behavior of Milk Consumption of IPB Fapet's Milk and Processed Products}

Based on Spearman's correlation test in Table 4 shows that gender has a significant positive correlation with the frequency of consumption of Fapet's milk. The results showed that male students had a higher frequency of Fapet milk consumption than female. In addition, pocket money and large families have a significant negative correlation with the frequency of consumption. It has a meaning that the lower the allowance and the bigger the family, the higher the frequency of student consumption to Fapet's milk. Meanwhile, the father's occupation also has a significant negative correlation with the frequency of consumption. This shows that the father who worked the frequency level of consumption of Fapet milk will decrease.

Meanwhile the AIDA variables, there is a significant and positive correlation between the variables of awareness with interest and action. It shows that the higher the awareness of the students, the higher the interest and the students' actions to consume Fapet's milk. In addition, the results showed there was a significant positive correlation between interest and desire. This shows that the higher the interest of the student, the higher the students desire to consume Fapet's milk. The results also show that awareness, interest, and action have a significant positive correlation with consumption behaviour of Fapet's milk based on frequency and number of consumed species. This has the meaning that the higher awareness, interest, and action the higher the frequency of consumption and the more types of Fapet's milk consumed.

Tabel 4 Coefficient correlation of student characteristics, family characteristics, awareness, interest, desire, action, and consumption behaviour

\begin{tabular}{|c|c|c|c|c|c|c|}
\hline \multirow[b]{2}{*}{ Variables } & \multirow[b]{2}{*}{ Awareness } & \multirow[b]{2}{*}{ Interest } & \multirow[b]{2}{*}{ Desire } & \multirow[b]{2}{*}{ Action } & \multicolumn{2}{|c|}{ Consumption Behavior } \\
\hline & & & & & Frequency & $\begin{array}{l}\text { Number } \\
\text { of types }\end{array}$ \\
\hline Age & -0.085 & -0.106 & -0.077 & -0.048 & -0.019 & 0.007 \\
\hline Gender & 0.073 & 0.073 & 0.106 & $0.141^{*}$ & $0.180^{* *}$ & 0.108 \\
\hline $\begin{array}{l}\text { Pocket } \\
\text { Money }\end{array}$ & 0.048 & 0.076 & 0.020 & 0.078 & $-0.146^{*}$ & 0.018 \\
\hline $\begin{array}{l}\text { (Rp/month) } \\
\text { Father's } \\
\text { occupation }\end{array}$ & 0.076 & -0.007 & 0.012 & $-0.204^{* *}$ & $-0.178^{*}$ & -0.056 \\
\hline $\begin{array}{l}\text { Mother's } \\
\text { occupation }\end{array}$ & -0.023 & -0.012 & 0.047 & $0.145^{*}$ & 0.089 & 0.013 \\
\hline Family sizes & -0.082 & -0.063 & 0.025 & 0.050 & $-0.198^{*}$ & 0.017 \\
\hline $\begin{array}{l}\text { Family } \\
\text { income } \\
\text { (Rp/month) }\end{array}$ & 0.045 & 0.029 & 0.029 & -0.083 & 0.112 & -0.078 \\
\hline
\end{tabular}




\begin{tabular}{|c|c|c|c|c|c|c|}
\hline \multirow[b]{2}{*}{ Variables } & \multirow[b]{2}{*}{ Awareness } & \multirow[b]{2}{*}{ Interest } & \multirow[b]{2}{*}{ Desire } & \multirow[b]{2}{*}{ Action } & \multicolumn{2}{|c|}{ Consumption Behavior } \\
\hline & & & & & Frequency & $\begin{array}{l}\text { Number } \\
\text { of types }\end{array}$ \\
\hline Awareness & & $0.220^{* *}$ & 0.131 & $0.139^{*}$ & $0.214^{* *}$ & $0.210^{* *}$ \\
\hline Interest & & - & $0.350^{* *}$ & 0.098 & $0.155^{*}$ & $0.166^{*}$ \\
\hline Desire & & & - & 0.052 & 0.038 & 0.095 \\
\hline Action & & & & - & $0.388^{* *}$ & $0.447^{k *}$ \\
\hline
\end{tabular}

Description: ${ }^{*}$ significance at $\mathrm{p} \leq 0.05 ;{ }^{* * *}$ significance at $\mathrm{p} \leq 0.01$

\section{Factors Affecting Consumption Behavior of Fapet's Milk and Processed Products}

Table 5 shows that the regression test results on the frequency of consumption of Fapet milk with Adjusted R square value of 0.184 . That is, only 18.4 percent variables in the study that influenced the frequency of consumption of Fapet's milk, the rest influenced by variables that are not examined. Meanwhile, the results of regression test on the number of types of Fapet's milk consumed with Adjusted R square value of 0.235 . That is, only 23.5 percent percent variables in the study that influenced the amount of milk Fapet consumed, the rest influenced by the variables that are not examined. This shows that the influence of variables in the study on the number of types of Fapet's milk consumed higher than the frequency of consumption of milk Fapet.

The results showed that gender $(\beta=3.606 ; p$-value $\leq 0.1)$, awareness $(\beta=$ 0.139 ; $p$-value $\leq 0.05)$, as well as action $(\beta=16.918$; $p$-value $\leq 0.05$ ) have a significant positive influence on the frequency of consumption of milk Fapet. This means that male students are more likely to consume Fapet's milk than female students. Each increase of one unit of awarenees will raise the frequency of consumption by 0.139 points. Each increase of one unit of action increases the frequency of consumption by 16,918 points. In addition, the pocket money ( $\beta=-$ 7.698E-6) and the large family $(\beta=-2.138)$ had a significant negative influence on the frequency of consumption of Fapet's milk at $p$-value $\leq 0.05$. This means that every increase of one rupiah pocket money will reduce the frequency of consumption of Fapet's milk of 7.698E-6 points and each increase of one family member will decrease the frequency of consumption of Fapet's milk for 2.138 points.

Other results also show that awareness $(\beta=0.007)$ and action $(\beta=1.722)$ have a significant positive influence on the amount of Fapet's milk consumed at $p$-value $\leq 0.05$. It has the meaning of each increase of one unit of awareness then increase the amount of Fapet's milk consumed by 0.007 points. Each increase of one unit of action will increase the amount of Fapet's milk consumed by 1.722 points. 
Widaryanti \& Retnaningsih / Journal of Consumer Sciences, 2018, Vol. 03, No. 01

Tabel 5 Factors that influence the behaviour of milk consumption of IPB Fapet and processed products

\begin{tabular}{|c|c|c|c|c|c|c|}
\hline \multirow{3}{*}{ Variables } & \multicolumn{3}{|c|}{ Frequency of Consumption } & \multicolumn{3}{|c|}{ Number of types } \\
\hline & Unstandardized & Standardized & $\mathrm{Siq}$ & Unstandardized & standardized & Sig. \\
\hline & $\beta$ & $\beta$ & & $\mathrm{B}$ & $\beta$ & \\
\hline Constanta & -16.756 & & 0.457 & -2.817 & & 0.030 \\
\hline Age & 0.693 & 0.045 & 0.480 & 0.082 & 0.090 & 0.146 \\
\hline $\begin{array}{l}\text { Gender } \\
(0=\text { male; } \\
1=\text { female })\end{array}$ & 3.606 & 0.121 & $0.065^{*}$ & 0.058 & 0.033 & 0.604 \\
\hline $\begin{array}{l}\text { Pocket } \\
\text { Money }\end{array}$ & $-7.698 \mathrm{E}-6$ & -0.166 & $0.013^{* *}$ & $2.051 \mathrm{E}-9$ & 0.001 & 0.991 \\
\hline $\begin{array}{l}\text { Father's } \\
\text { occupation } \\
(0=\text { working; } \\
1=\text { not } \\
\text { working) }\end{array}$ & -9.775 & -0.110 & 0.102 & 0.334 & 0.063 & 0.329 \\
\hline $\begin{array}{l}\text { Mother's } \\
\text { occupation } \\
(0=\text { working; } \\
1=\text { not } \\
\text { working) }\end{array}$ & 1.051 & 0.033 & 0.619 & -0.138 & -0.073 & 0.254 \\
\hline Family size & -2.138 & -0.148 & $0.022^{* *}$ & 0.027 & 0.031 & 0.615 \\
\hline $\begin{array}{l}\text { Family } \\
\text { income }\end{array}$ & $4.370 \mathrm{E}-7$ & 0.084 & 0.219 & $-2.221 \mathrm{E}-8$ & -0.072 & 0.276 \\
\hline Awareness & 0.139 & 0.164 & $0.014^{* *}$ & 0.007 & 0.140 & $0.030^{* *}$ \\
\hline Interest & 0.162 & 0.108 & 0.125 & 0.006 & 0.062 & 0.363 \\
\hline Desire & -0.069 & -0.045 & 0.518 & 0.004 & 0.048 & 0.484 \\
\hline Action & 16.918 & 0.265 & $0.000^{* *}$ & 1.722 & 0.455 & $0.000^{* *}$ \\
\hline $\mathrm{F}$ & & 5.272 & & & .819 & \\
\hline Sig. & & 0.000 & & & .000 & \\
\hline Adjusted $R^{2}$ & & 0.184 & & & .235 & \\
\hline
\end{tabular}

Description: ${ }^{*}$ significance on $\mathrm{p} \leq 0.1 ;{ }^{* *}$ significance on $\mathrm{p} \leq 0.05$

\section{Discussion}

A person's purchasing and consumption decisions usually begin with the recognition of needs that are aware of the existence and benefits of a product. Usually, each product has its own peculiarities. When the particularity is attached to the consumer, then the consumer will be interested to find more information about the product so that consumer have an understanding. Then, awareness leads to interest; interest leads to the desire to meet the needs until the consumer ultimately determines the choice to act or behaviour (Ranjbarian et al., 2011). These steps are included in the AIDA model which is one of the popular response models for marketing that serves as a guide to implementing marketing activities (Budiawan et al., 2017). 
Based on the results of research on the concept of AIDA, awareness and interest in dairy products Husbandry at high category with the percentage of each 83.3 percent and 60.3 percent. This shows that awareness has a correlation with consumer interest in consuming a product (Rehman et al., 2014). Students desire in dairy products Husbandry middle category as much as $(74.2 \%)$. This is following the marketing theory that states that consumer interest does not necessarily influence consumer desire in consuming a product. Students action is in the high category (94.3\%) with the assumption that does not consume classified as low category and consume as high category.

Almost half $(49.8 \%)$ of students still rarely consume Fapet's milk with frequencies below 16 time/month. Meanwhile, as many as 56.5 percents of students are very often consume milk and other dairy products with a frequency of consumption above 28 times/month. In addition, 79.4 percent of students only consume 1-2 types of Fapet's milk. In dairy products and other processed products with other brands, students consume 3-4 types of milk and processed products with a percentage of 70.3 percent. This suggests that milk and its dairy products with other brands are easier to find and obtain than Fapet's milk so the frequency of consumption is very frequent and the number of types consumed more. Almost all (93.3\%) students consume pasteurized milk flavor with Fapet's milk brand. Not just pasteurized milk flavor, more than half $(51.2 \%)$ of students consume UHT milk flavor. This suggests that young people seen a product from taste (Kurajdová et al., 2015).

Based on the results of the study showed that gender has a significant positive correlation and significant positive influence on the frequency of consumption of Fapet's milk. This shows that the frequency level of consumption of Fapet's milk on male students is higher than female. This is following research Oktoriyana et al. (2014) which states that the individual difference factor can directly influence the buying interest. In addition, father who work has a significant negative correlation to the frequency of consumption. That is when the father worked the frequency level of consumption of Fapet's milk will decline. This shows that students with working father prioritize to buy other goods and services. This is following Kotler and Armstrong's (2008) assertion that one's work will influence the goods and services they will buy.

The study also found that pocket money has a significant negative influence on the frequency of consumption of milk Fapet. That is, the higher the pocket money, the less frequent consumption of Fapet's milk. This indicates that students whose pocket money is high, priority to consume other products than milk. Meanwhile, large families has a significant negative correlation and influence on the frequency of consumption of milk consumed Fapet. This shows that the more family members, the less frequency of consumption of Fapet's milk. It shows that social factors such as family also greatly influence the decision process. According to Yayar (2012) states that the socio-economic and demographic characteristics of households play an important role in consuming milk. 
The AIDA model is one of the most important decision-making processes on awareness, interest, desire, and action (Johar et al., 2015). The study found that the awareness has a very significant positive correlation with interest, and interest has a very significant positive correlation with the desire. This shows that the higher the awareness the higher the interest and the higher the student's desire to consume Fapet's. Meanwhile, the results also showed that the awareness has a significant positive correlation with the action. This is in contrast to research conducted by Murdiani (2012) and Anugrah (2013) which says that there is no significant relationship between awareness and action. The results show that each component in the AIDA model is significant (Gharibi et al., 2012). However, in this study, there is no correlation between desire and action. This is because every consumer may find barriers to reach the stage of action, such as when will consume the product has been exhausted or need time to buy Fapet's milk and processed products because it is not available in all places. This is reinforced by the statement of Ghirvu (2013) that many consumers express interest and desire for a product, but they do not reach the final stage of the acquisition process of buying or consuming.

Other results showed that the awareness and action influenced milk consumption behavior by the frequency of consumption and the number of types that are consumed.This is in line with the research by Hadiyati (2016) that the AIDA model influences purchasing decisions.Variable awareness has a significant impact because it is the first step to incorporate a brand into the group stage of the alternative choices of information search and alternative evaluation phase (Fazri 2009).

Almost all (99.5\%) students were exposed to information from Fapet milk products from friends. Only 66 percent of students are exposed through the bazaar. Consumers will complete the information obtained with other information before they decide to consume it or not. Consumers also store in their memories a variety of information, feelings, and past experiences that can be remembered when making decisions (Wijaya 2012).

The results of the Consumer Response Index (CRI) at each stage of the response in this study indicate that all values of response stages are almost 100.0 percent. The results of CRI analysis of Fapet dairy products and their processed products showed that from 209 students who were exposed to information about Fapet's milk products only 165 students survived until the stage of consuming. CRI calculatio results obtained by 78.9 percent. High CRI figures show high consumer response to the products offered. This means that the higherCRI numbers obtained the more effective marketing communications conducted (Main et al. 2009). This shows that Fapet's milk products and marketing communications conducted by PT D-Farm Agriprima have been effective. While viewed from the consumer side, the frequency in consuming Fapet milk belongs to the rare category ( $<16$ times/month). This is because some students consume more milk with other brands commonly consumed and available in all places so that students are easier to obtain these products compared with milk Fapet. Meanwhile, some students are also more likely to consume UHT milk that is easy to obtain. The limitation of this research 
is the recall method used when filling the questionnaire on consumption behaviour variables so that researchers do not know for sure whether the answers given by students true or not.

\section{Conclusion and Recommendation}

\section{Conclusion}

All students in this study were exposed to Fapet's milk products. Levels of student awareness, interest, and action on Fapet dairy products are in the high category, and the desire of students to consume Fapet's milk is in the moderate category. The frequency of consumption of Fapet milk at the student is in a low category that is less than 16 time/month. The amount of Fapet's milk consumed by IPB students is in 1 to 2 types. Type of Fapet's milk most consumed by students is pasteurization milk flavor.

There is a significant positive correlation between consciousness with attraction, interest with desire, whereas desire has no relation to action. Factors that significantly influence the frequency of consumption of Fapet's milk are gender, pocket money, family size, awareness, and action. This means that students of the male gender are more likely to consume Fapet's milk than female students. In addition, socio-economic factors also influence consumption behaviour. Meanwhile, factors that significantly influence the number of types of fapet's milk consumed are awareness and action. The result of CRI calculation on Fapet Milk product was obtained at 78.9 percent. Its meaning, marketing strategy done by producer have effective.

\section{Recommendation}

Based on the results of research, the advice to consumers is to love local products such as milk Fapet. Suggestions for milk producers to further develop the media campaign for its products so that consumers are interested in more easily to access information. In addition to appreciating local products, can also increase the amount of milk consumption in Indonesia. Suggestions for further research is to use a broader sample of research to communities outside the IPB environment to know the general public response and can generalize the effectiveness of milk products Fapet.

\section{Reference}

Anjasari, B. (2010). Pangan Hewani Fisiologi Pasca Mortem dan Teknologi. Ed ke-1. Yogyakarta (ID): Graha Ilmu.

Anugrah, N.L. (2013). Perilaku Penggunaan Produk Day Cream Rumput Laut: Analisis Model AIDA dan CRI [skripsi]. Institut Pertanian Bogor.

Bousbia, A., Boudalia, S., Chelia, S., Oudaifia, K., Amari, H., Benidir, M., Belkheir, B., Hamzaoui, S. (2017). Analysis of factors affecting consumer behaviour of dairy products in Algeria: A case study from the region of Guelma. International Journal of Agriculture Research,12(2), 93-101. doi:0.3923/ijar.2017.93.101.

Budiawan, R., Satria, A., Simanjuntak, M. (2017). The quasi experimental study of the influence of advertising creativity and exposure intensity toward 
purchasing action with AIDA approach. Independent Journal of Management \& Production,8(2), 378-394. doi: 10.14807/ijmp.v8i2.526.

Familmaleki, M., Aghighi, A., Hamidi, K. (2015). Analyzing the impact of promotion mix on consumers purchase decision. Advanced Social Humanities and Management, 2(1), 71-81.

Fazri, A. (2009). Mengukur jumlah paparan TVC yang efektif biaya untuk meninmbulkan dampak attention, interest, desire, dan action pada konsumen di kota Jambi. Jurnal Manajemen Pemasaran Modern, 1(1).

Gharibi, S., Danesh, S.Y.S., Shahrodi, K. (2012). Explain the effectiveness of advertising using the Aida model. Interdisciplinary Journal of Contemporary Research in Business, 4(2).

Ghirvu, A.I. (2013). The AIDA model for advergmaes. The Usv Annals of Economics and Public Administration, 13(17), 90-98.

Hadiyati, E. (2016). Study of Marketing Mix and Aida Model to Purchasing on Line Product in Indonesia. British Journal of Marketing Studies, 4(7), 49-62.

Johar, D.S., Kumadji, S., Mawardi, M.K. (2015). Pengaruh AIDA (attention, interest, desire, action) terhadap efektifitas iklan online (survei pada pembeli di toko online adorable project). Jurnal Administrasi Bisnis, 26(1).

Kotler, P., Armstrong, G. (2008). Prinsip-Prinsip Pemasaran Jilid 1. Ed ke-12. Sabran B, penerjemah. Jakarta (ID): Erlangga.

Kurajdová, K., Petrovičová, J.T., Kaščáková, A. (2015). Factors influencing milk consumption and purchase behavior evidence from Slovakia. Procedia Economics and Finance,34, 573-580.

Li, J., Yu, H. (2013). An innovative marketing model based on Aida: a case from e-bank campus-marketing by china construction bank. Scientific Research, 5, 47-51.

Murdiani, I. (2012). Perilaku Konsumsi Mahasiswa terhadap Produk pangan IPB: Analisis Model AIDA [skripsi]. Institut Pertanian Bogor.

Oktoriyana, A., Sumarwan, U., Hartoyo. (2014). Perumusan strategi pemasaran fry counter dengan pendekatan model AIDA. Jurnal Ilmu Keluarga dan Konsumen, 7(2), 103-112.

Rawal, P. (2013). AIDA marketing communication model: stimulating a purchase decision in the minds of the consumers through a linear progression of steps. International Journal of Multidisciplinary Research in Social \& Management Sciences, 1, 37-44.

Ranjbarian, B., Shaemi, A., Jolodar, S.Y.E. (2011). Assessing the effectiveness of electric conservation advertisements in Isfahan channel television. International Business Research, 4(3). doi: 10.5539/ibr.v4n3p194.

Rehman, F.U., Nawaz, T., Ilyas, M., Hyder, S. (2014). A comparative analysis of mobile and email marketing using AIDA model. Journal of Basic and Applied Scientific Research,4(6), 38-49.

Rogers, E.M. (2003). Diffusion of Innovations. $5^{\text {th }}$ ed. New York: Free Press.

Sis, A.R.A., Albari. (2015). Pengukuran efektifitas pengiklanan lingkungan melalui iklan televisi (pendekatan model AIDA), 19(1), 16-26. Universitas Islam Indonesia.

Suryono, Khomsan, A., Setiawan, B., Martianto, D., Sukandar, D.(2007). Pengaruh pemberian susu terhadap indeks massa tubuh dan kepadatan tulang punggung remaja pria. Jurnal Gizi dan Pangan, 2(1),1-7.

Ugonna, I.A., Ndubisi, E.C., Otugo, N.E., Eze, P.C., Akabogu, O.C. (2014). Anatomical effects of billboard advertising on consumers' purchase intent of beer. International Journal of Innovative Research in Management, 7, 14-24.

Utama, S.S., Andadari, R.K., Matrutty, E.S.H.R. (2009). Efektivitas iklan televisi partai gerindra berdasarkan metode Customer Response Index (CRI) di Salatiga. Jurnal Ekonomi dan Bisnis, 15(1), 89-102. 
Wijaya BS. 2012. The development of hierarchy of effects model in advertising. International Research Journal of Business Studies.5(1).

Yayar, R. (2012). Consumer characteristics influencing milk consumption preference. The Turkey case. Theoretical and Applied Economics, 19(7), 25-42. 